\title{
Kansainvälinen aikuistutkimus arvioi väestön perustaitoja
}

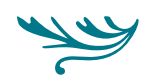

Investointi lukutaitoon hyödyttää paitsi yksittäisiä henkilöitä elämänlaadun

ja ansiotason paranemisena, myös koko yhteiskuntaa terveydenhuollon, rikollisuuden ja sosiaaliturvan kustannusten vähenemisenä. Lukutaidon ohessa numerotaitoa ja ongelmaratkaisutaitoa voidaan pitää jopa perustavanlaatuisena ihmisoikeutena. Uusi kansainvälinen aikuistutkimus pyrkii mittaamaan näitä taitoja moniulotteisesti.

VIIMEISEN KAHDEN vuosikymmenen aikana on toteutettu kaksi aikuisten lukutaidon ja perustaitojen kansainvälistä arviointitutkimusta. Ensimmäinen oli vuosina 1994-1998 toteutettu IALS (International Adult Literacy Survey), johon myös Suomi osallistui. Toinen oli vuosina 2002-2006 toteutettu ALL (Adult Literacy and Life Skills Survey), johon Suomi ei osallistunut. Nyt käynnissä oleva Kansainvälinen aikuistutkimus PIAAC (Programme for the International Assessment of Adult Competencies) jatkaa tätä tutkimusten sarjaa.

PIAAC on Taloudellisen yhteistyön ja kehityksen järjestö OECD:n (Organisation for Economic and Cultural Development) aloitteesta käynnistetty aikuisväestön työ- ja arkielämän perustaitojen osaamista ja käyttöä arvioiva tutkimus. Keskeisenä kiinnostuksen kohteena ovat aikuisten lukutaito, numerotaito ja ongelmanratkaisutaito tietoteknisessä ympäristössä. Tavoitteena on selvittää, ovatko aikuisten perustaidot sillä tasolla, että he ovat valmiita vastaamaan tulevaisuuden mukanaan tuomiin ehkä nopeisiin ja yllättäviinkin muutoksiin ja haasteisiin.

Tutkimukseen osallistuu 25 maata. Tutkimus- ta johtaa ja koordinoi Educational Testing Service (ETS) USA:sta, ja sen toteuttamiseen osallistuu laaja kansainvälinen tutkimusorganisaatioiden yhteenliittymä. Tutkimuksen Suomen osuuden toteutuksesta vastaa Jyväskylän yliopiston Koulutuksen tutkimuslaitos, ja Tilastokeskus suorittaa tutkimuksen tiedonkeruun. Tutkimuksen kansallisia rahoittajia ovat opetus- ja kulttuuriministeriö sekä työ- ja elinkeinoministeriö, ja tutkimuksen ohjaukseen osallistuu myös Opetushallitus.

Tutkimuksen perusjoukon muodostavat kaikki 16-65-vuotiaat Suomessa asuvat henkilöt, riippumatta esimerkiksi äidinkielestä tai synnyinmaasta. Näitä henkilöitä asuu Suomessa noin 3,5 miljoonaa. Tästä väestöstä on tutkimukseen poimittu edustava otos. Otoskoko on 8099 henkilöä, ja tiedonkeruun tavoitteena on 5300 toteutunutta haastattelua.

Tutkimuksen tiedonkeruu alkoi syyskuun alussa 2011 ja päättyi maaliskuun lopussa 2012. Tilastokeskuksen tilastohaastattelijat toteuttivat tiedonkeruun käyntihaastatteluina. Tiedonkeruu tehtiin sekä suomeksi että ruotsiksi. Haastattelun ensimmäinen osa oli haastattelijan tekemä tietokoneavusteinen tausta- 
kysely. Toisen osan muodosti perustaitoja mittaavien tehtävien itsenäinen tekeminen. Tehtävät tehtiin pääsääntöisesti tietokoneella, mutta mikäli vastaaja ei osannut käyttää tietokonetta riittävän hyvin tai ei halunnut käyttää sitä, tehtävät tehtiin perinteisiin paperisiin tehtävävihkoihin. Ennen tehtävien tekemistä tietokoneen käytön perustaitojen hallinta varmistettiin tekemällä pieni joukko helpohkoja tehtäviä.

Varsinaista päätutkimusta edelsi laaja esitutkimus, jonka tiedonkeruu toteutettiin keväällä 2010. Esitutkimukseen osallistui Suomessa noin 1300 henkilöä. Esitutkimuksessa kerättyjä tietoja käytettiin tutkimusvälineiden kehittämiseen ja päätutkimuksen valmisteluun, eikä esitutkimusaineistosta raportoida tuloksia. Tutkimuksen ensimmäiset tulokset julkaistaan lokakuussa 2013. Tutkimusaineisto vapautuu sen jälkeen tutkijoiden käyttöön.

\section{TUTKITTAVAT PERUSTAIDOT}

Yhteiskunnassa ja työelämässä tapahtuvat muutokset asettavat aikuisten osaamiselle uusia vaatimuksia. Työelämässä tarvittavat tiedot ja taidot kehittyvät kaiken aikaa, ja niitä täytyy päivittää koko työelämän ajan. Työelämässä toimivilta edellytetään sellaisia perusvalmiuksia ja perustaitoja, että he kykenevät nopeasti ja joustavasti reagoimaan työelämässä tapahtuviin muutoksiin ja sen tuomiin koulutustarpeisiin.

Tämän kehityksen takana on ainakin kaksi merkittävää tekijä: globalisaatio ja tietotalous (Keeley 2007, 13). Globalisaatio vähentää kansallisvaltioiden rajojen merkitystä ja kansantaloudet ovat yhä enemmän sidoksissa toisiinsa. Vähän taitoja ja osaamista edellyttävät työt uhkaavat siirtyä, ja ovat jo osittain siirtyneet, kehittyneistä maista matalan palkkatason maihin. Tiedon ja sen käsittelyn arvo on tullut ilmeiseksi. Tuloerot kasvavat paljon ja vähän koulutettujen välillä. Köyhyys ei tarkoita vain rahan puutetta, vaan myös koulutuksen, terveyden ja hyödyllisten kontaktien puutetta, eli puutetta myös niistä resursseista, joiden varaan taloudellinen menestyskin rakentuu.

Teknologian ja ennen kaikkea tietokoneen kehitys voi muuttaa työelämän luonnetta nopeammin kuin ihmiset pystyvät muuttamaan taitojaan. Työelämässä tehtävät, joissa edellytetään asiantuntijuu- teen yhdistyviä ongelmanratkaisutaitoja ja laaja-alaisia viestintätaitoja, ovat lisääntyneet. Rutiinityö, niin helposti tietokoneelle siirrettävissä oleva henkinen kuin ruumiillinenkin, sen sijaan on vähentynyt. (Levy 2010.)

Aikuisten kansainvälisen lukutaitotutkimuksen (IALS) tulokset osoittivat, että aikuisväestön lukutaidon tasossa on suuria eroja sekä kansallisesti että kansainvälisesti (OECD \& Statistics Canada 1995; OECD \& Statistics Canada 2000; OECD, HRDC \& Statistics Canada 1997). Kaikissa osallistujamaissa oli henkilöitä, joiden lukutaito oli puutteellinen. Koulutustaso ennusti parhaiten lukutaidon tasoa. Ikä oli toinen tärkeä lukutaidon selittäjä. Vanhimmat ikäluokat olivat lukijoina yleisesti ottaen nuorempia huonompia. Myös korkea sosioekonominen tausta ja hyvä vanhempien koulutus olivat yhteydessä hyvään lukutaitoon. Lukutaito oli parempi niillä, jotka käyttivät taitoaan aktiivisesti niin työssään kuin jokapäiväisessä toiminnassaan. Heikolla lukutaidolla varustetuilla henkilöillä oli muita suurempi todennäköisyys joutua työttömiksi, ja hyvä lukutaito näkyi parempina ansiotuloina. Hyvä lukutaito oli yhteydessä myös parempaan terveyteen ja terveellisempiin elämäntapoihin sekä aktiivisempaan yhteiskunnalliseen toimintaan.

Tutkimukseen osallistuneiden 20 maan vertailu osoitti, että asiatekstien lukutaidossa suomalaiset olivat kansainvälistä huipputasoa, ja maakeskiarvojen mukaisessa järjestyksessä Suomi oli toinen Ruotsin jälkeen. Myös dokumenttien lukutaito oli kansainvälisesti verrattuna hyvä (järjestyksessä neljäs). Sen sijaan kvantitatiivinen eli matematiikkaa soveltava lukutaito osoittautui kansainvälisesti vain keskitasoiseksi ja selvästi muiden Pohjoismaiden tasoa heikommaksi (järjestyksessä seitsemäs). Tutkimustulosten perusteella arvioitiin, että Suomenkin aikuisissa on niitä, joiden lukutaito ei riitä elinikäisen oppimisen välineeksi eikä tietoyhteiskunnan tarpeisiin. Aikuisväestöstä 15 prosentilla eli noin puolella miljoonalla aikuisella havaittiin lukutaidossa ainakin yhdellä osa-alueella vakavia puutteita. (Linnakylä ym. 2000.)

Numerotaito on yhtä olennainen kansalaisten perustaito kuin lukutaitokin. Numeeristen ja ma- 
temaattisten taitojen osaamista ja merkitystä aikuisten elämässä ei ole tutkittu yhtä paljon kuin lukutaitoa, mutta niiden merkitys on kuitenkin hyvin tiedostettu. Numerotaitoa aikuiset tarvitsevat niin työssä, opiskelussa kuin jokapäiväisessä elämässään. Kaikki joutuvat käsittelemään yhä enemmän numeerisessa muodossa esitettyä tietoa eri elämäntilanteissa, ja jokainen tarvitsee numerotaitoa ainakin jokapäiväisen taloutensa hoitamisessa. Numerotaitoa, kuten lukutaitoakin, voidaan pitää jopa perustavanlaatuisena ihmisoikeutena (NIACE Committee of Inquiry on Adult Numeracy Learning 2011, 10).

Parsons ja Bynner (2005) käyttivät kahta pitkittäisaineistoa (National Child Development Study 1958 ja British Cohort Study 1970) ja halusivat selvittää, onko numerotaito vähemmän tärkeä kuin lukutaito ja voidaanko numerotaidon vaikutukset erottaa lukutaidon vaikutuksista. Huonolla lukutaidolla ja numerotaidolla varustetut lopettivat koulunkäyntinsä aikaisemmin kuin hyvillä taidoilla

TEKNOLOGIAN JA ENNEN

\section{KAIKKEA TIETOKONEEN}

KEHITYS VOI MUUTTAA

TYÖELÄMÄN LUONNETTA

NOPEAMMIN KUIN IHMISET

PYSTYV ̈̈T MUUTTAMAAN

TAITOJAAN. varustetut. Heidän joukossaan oli myös enemmän ilman tutkintoa olevia. Huonolla numerotaidolla oli negatiivinen vaikutus 1980-luvun laman aikana miesten työllistymiseen. Myös myöhemmin huono numerotaito lisäsi työttömyyden riskiä, vaikutti ansioita pienentävästi ja yhdistyi heikompaan taloudelliseen hyvinvointiin. Naisilla huonon numerotaidon negatiivinen vaikutus oli suurempi kuin huonon lukutaidon, mutta miehillä ei tätä eroa ollut. Kirjoittajat arvelevat työelämän muutosten olevan sellaisia, että nuoria naisia kiinnostavat työt edellyttävät entistä enemmän numeerisia taitoja.

Carpentieri ym. (2010) havaitsivat myös, että huonolla numerotaidolla varustetut ansaitsivat vähemmän, olivat useammin työttöminä ja osallistuivat harvemmin työpaikkakoulutukseen. Lisäksi heillä oli muita useammin pitkäaikaissairauksia ja depressiota ja heidän yhteiskunnallinen aktiivisuutensa oli vähäi- sempää. Tietotekniikka tuntui kiinnostavan heitä muita vähemmän, heiltä puuttui muita useammin internetyhteys, heillä oli harvemmin kotitietokone ja he käyttivät kotitietokonetta muita harvemmin, jos heillä oli sellainen. Kodin korkea sosioekonominen tausta kasvatti todennäköisyyttä, että henkilöllä oli aikuisena hyvä numerotaito. Hyvään numerotaitoon liittyi myös suurempi kiinnostus omien lasten tulevaisuutta kohtaan.

Aikuisten perustaitojen hallinta ei ole tärkeätä ainoastaan heidän itsensä kannalta, vaan heidän hyvistä taidoistaan hyötyvät myös heidän lapsensa. Brittiläisessä tutkimuksessa (De Coulon ym.) selvitettiin vanhempien luku- ja numerotaidon yhteyttä heidän lastensa kognitiivisiin suorituksiin. Aikuisilta testattiin 34 vuoden iässä heidän perustaitonsa, ja samalla myös arvioitiin heidän lastensa kognitiiviset taidot. Tutkijat havaitsivat positiivisen yhteyden vanhempien luku- ja numerotaidon ja heidän lastensa kognitiivisen kehityksen välillä. Vanhempien paremmat taidot ilmenivät myös heidän lastensa parempina kognitiivisina taitoina. Lukutaidon vaikutus oli hieman suurempi kuin numerotaidon. Tämä vaikutus oli olemassa riippumatta vanhempien koulutuksesta tai vanhempien lapsena osoittamista kyvyistä.

Perustaitojen hallinnassa on kysymys myös tasa-arvosta ja oikeudenmukaisuudesta. Tasa-arvon näkökulmasta ei voi olla hyväksyttävä tilanne, jos jotkin väestöryhmät ovat systemaattisesti heikompia taidoiltaan muihin verrattuna. Tämä rajoittaa niin heidän kouluttautumis- ja työllistymismahdollisuuksiaan kuin heidän arkielämän hallintaansa, heijastuu ongelmina heidän taloudellisessa ja sosiaalisessa hyvinvoinnissaan ja terveydentilassaan, ja näkyy jopa heidän lastensa osaamisessa.

\section{PERUSTAITOJEN ARVIOINTI}

PIAAC:ssa arvioidaan suoraan tehtäviä tekemällä kolmea aikuisten perustaitoa: lukutaito, numerotai- 
to ja ongelmanratkaisutaito tietoteknisessä ympäristössä. Arviointitehtävät muistuttavat erilaisia työ- ja arkielämän tilanteita, joissa vastaajan tarvitsee käyttää arvioinnin kohteena olevia taitoja. Jokaiseen tehtävään sisältyy yksi tai useampia kysymyksiä, joihin vastaajan on löydettävä ratkaisu tehtävässä annetun tiedon perusteella. Jokaisen arvioitavan osa-alueen arviointikehyksen ja tehtävät on työstänyt kunkin alueen kansainvälinen asiantuntijaryhmä. Tässä työssä on hyödynnetty IALS- ja ALL-tutkimuksien teoreettista työtä ja niissä kehitettyjä tehtäviä.

Jokaisella tutkitulla osa-alueella vastaajille lasketaan tehtyjen tehtävien perusteella heidän osaamistaan kuvaava pistemäärä. Kaikille osallistujamaille yhteisen mitta-asteikon muodostamisessa käytetään osioanalyysimallia, jonka avulla voidaan myös varmistaa tehtävien yhtenäinen toimivuus eri maissa. Mallin avulla pystytään samanaikaisesti tarkastelemaan sekä mittarin ominaisuuksia että estimoimaan tutkittavien henkilöiden taitoja kuvaavat pistemäärät. (Mallin käyttöä IALS-tutkimuksessa esittelevät Linnakylä ym. 2000, 169-173.) Lisäksi osaamispistemäärän perusteella määritellään, mille suoritustasolle viisiluokkaisella asteikolla henkilö sijoittuu. Osaamispistemäärän luotettavaan laskemiseen ja taitotason määrittelyyn tarvitaan suuri joukko tehtäviä, joiden on vaihdeltava vaikeustasoiltaan ja sisällöiltään. Kaikki tehtävät testattiin laajassa esikokeessa, ja psykometrisilta ominaisuuksiltaan parhaat valittiin päätutkimukseen.

\section{LUKUTAITO}

Lukutaidon määritelmän pohjana on käytetty IALS:n ja ALL:n määritelmää, mutta PIAAC:n lukutaidon kansainvälinen asiantuntijaryhmä on laajentanut määritelmää niin, että se sisältää myös uusia lukutaitovaatimuksia. Lukutaito määritellään PIAAC:ssa seuraavasti (OECD 2012, 20): "Lukutaito on kirjoitettujen tekstien ymmärtämistä, arvioimista ja käyttämistä sekä niiden lukemiseen sitoutumista yhteiskuntaelämään osallistumiseksi, lukijan omien tavoitteiden saavuttamiseksi sekä tietojen ja valmiuksien kehittämiseksi."

Määritelmässä kirjoitetuilla teksteillä ei tarkoiteta vain paperille painettuja tekstejä, vaan myös erilaisilla sähköisillä näyttöruuduilla esitettäviä tekstejä. Nämä tekstit pitävät sisällään interaktiiviset tekstit, kuten sähköpostiin vastaaminen, hypertekstien kautta linkitetyt tekstit ja laajennettavat tekstit, joissa teksti on linkitetty yksityiskohtaisempaan tietoon.

Lukutaidon märïitelmä sisältää myös lukemaan sitoutumisen, eli asenteet lukemista kohtaan ja lukemisen harrastaminen. Lukemaan sitoutuminen vaihtelee huomattavasti henkilöiden välillä, ja se on tärkeä lukemiseen yhteydessä oleva tekijä. Lukemaan sitoutuminen korostaa sitä, että "lukutaitoinen henkilö paitsi osaa lukea myös arvostaa lukemista ja lukeminen on tiivis osa hänen päivittäistä elämäänsä. Lukemiseen sitoutunut lukija on kiinnostunut lukemisesta ja ennen kaikkea lukee aktiivisesti erilaisia tekstejä" (Sulkunen ym. 2010, 53).

Lukutaitokokeen laatimisessa oli kaksi tärkeää tekijää: ensinnäkin itse luettava teksti ja sen ominaisuudet, ja toiseksi luettuun tekstiin perustuva tehtävä ja sen vaatimat lukemisprosessit tai lukutaidon osaalueet. Lukutaitokoetta laadittaessa tarvittavia tekstejä jäsennettiin seuraavien ominaisuuksien mukaan:

- media: painettu ja sähköinen

- tekstimuoto: suorasanaiset tekstit, dokumentit, näiden kahden yhdistelmät ja monimuotoiset tekstit, jotka sisältävät erilaisia tekstimuotoja ja jotka on yhdistetty tiettyä tarkoitusta varten

- tekstityyppi: kuvaava, kertova, esittelevä, vaikuttamaan pyrkivä, ohjaava, sekä luettelon muodossa oleva teksti

- sähköisistä teksteistä: hyperteksti, interaktiivinen teksti sekä navigointityökalut

- lukemisen konteksti: ammatillinen, julkinen, opiskeluun liittyvä sekä yksityinen (koti, terveys, kuluttaminen, vapaa-aika).

Tehtävien muotoilussa tekstien vaatimia lukemisprosesseja jäsennettiin sen mukaan, mikä on lukemistilanteessa pääasiallinen tehtävä. Näitä lukemisen osa-alueita oli kolme:

- tiedon löytäminen ja tunnistaminen tekstistä

- tiedon yhdistäminen ja tulkitseminen tai tekstin osien suhteuttaminen toisiinsa

- tiedon arviointi ja pohdinta. 


\section{NUMEROTAITO}

IALS:ssa yksi lukutaidon osa-alue oli kvantitatiivinen lukutaito. PIAAC:ssa numerotaito halutaan kuitenkin arvioida selkeästi omana perustaitonaan. PIAAC:n numerotaidon määritelmä on kaksiosainen. Ensinnäkin itse numerotaito määritellään seuraavasti (OECD 2012, 34): "Numerotaidolla tarkoitetaan yksilön kykyä hankkia, käyttää, tulkita ja viestiä matemaattista tietoa ja ajattelua, jotta hän hallitsee aikuiselämän matemaattiset vaatimukset.”

Määritelmällä halutaan viitata myös siihen, että numerotaidossa eivät pelkästään kognitiiviset taidot ole tärkeitä. Myös uskomukset ja asenteet vaikuttavat siihen, miten tehokkaasti ja aktiivisesti henkilö kykenee käsittelemään aikuisen ihmisen elämässä esiintyviä erilaisia matemaattista osaamista vaativia tilanteita ja selviytymään niistä.

Numerotaidon määritelmää laajennetaan PIAAC:ssa sisältämään numeerisen toiminnan (OECD 2012, 34): "Numeerinen toiminta tarkoittaa todellisen elämän tilanteissa eri tavoin esitettyyn matemaattiseen sisältöön, tietoon ja ajatteluun liittyvän asian hallitsemista tai ongelman ratkaisua.”

Numeerisen toiminnan märitelmän lisääminen numerotaidon määritelmään on olennaista numerotaidon operationalisoinnin kannalta. Numeerisen toiminnan määritelmä sisältää neljä osaa: kontekstit, tiedon käsittely, matemaattinen sisältö, tieto ja ajattelu sekä esitystavat. Todellisilla tilanteilla viitataan neljään erilaiseen kontekstiin, joissa numerotaidon tarve ilmenee: (1) yksityinen, (2) ammatillinen, (3) julkinen ja (4) opiskeluun liittyvä. Näissä tilanteissa pitää pystyä käsittelemään matemaattista tietoa eri tavoin. Numerotiedon käsittelyssä erotetaan kolme osa-aluetta: (1) tiedon tunnistaminen ja löytäminen, (2) tiedon käyttäminen, sekä (3) tiedon tulkinta, arviointi, analysointi ja viestintä.

Matemaattinen sisältö, tieto ja ajattelu sisältävät neljä osa-aluetta: (1) lukumäärä- ja numerotuntemus, (2) ulottuvuudet ja muodot, (3) säännönmukaisuudet, yhteydet ja muutos, sekä (4) tietoaineisto ja todennäköisyys. Numeerista tietoa esitetään monin eri tavoin: kuvina, numeroina, matemaattisina symboleina, kaavoina, kuvioina, karttoina, taulukoina ja teksteinä.

\section{ONGELMANRATKAISUTAITO TIETOTEKNISESSÄ YMPÄRISTÖSSÄ}

Ongelmanratkaisutaidon arvioinnin tavoitteena on kattaa sellaisia ongelmia, joita ihmiset joutuvat ratkaisemaan käyttäessään tieto- ja viestintätekniikkaa. Näillä ongelmilla on seuraavia yhteisiä piirteitä (OECD 2012, 47):

Ongelman olemassaolo johtuu ensisijaisesti uudesta teknologiasta. Esimerkiksi internetissä on paljon tietoa, ja tiedon etsiminen ja kriittinen arviointi ovat internetin käytön keskeisiä taitoja.

Ongelman ratkaisu vaatii tietokoneella toimivien välineiden käyttöä. Ne muuttavat ongelman ratkaisussa tarvittavia menettelytapoja, vaikkakin itse ongelma ei välttämättä ole uusi. Esimerkkinä on vaikkapa henkilökohtaisten talousasioiden hallinta taulukkolaskentaohjelmalla.

Ongelmat vaativat tietoteknisen ympäristön hallitsemista, esimerkiksi tietokoneen ja internetselaimen käytön osaamista.

PIAAC:n ongelmanratkaisutaito tietoteknisessä ympäristössä määritellään seuraavasti (OECD 2012, 47): "Ongelmanratkaisutaito tietoteknisessä ympäristössä sisältää digitaalisen teknologian, viestintävälineiden ja tietoverkkojen hyödyntämistä tiedon hankkimisessa ja arvioimisessa, viestinnässä ja käytännön tehtävien tekemisessä. PIAAC:n ensimmäinen ongelmanratkaisututkimus keskittyy taitoihin ratkaista ongelmia henkilökohtaisissa, ammatillisissa ja kansalaisena toimimiseen liittyvissä tilanteissa, joissa edellytetään tarkoituksenmukaisten tavoitteiden asettamista, työskentelyn suunnittelemista sekä sähköisessä muodossa olevan tiedon hankkimista ja käyttämistä."

Määritelmän ensimmäisen virkkeen tarkoituksena on luoda perusta niin ensimmäiselle kuin tulevillekin ongelmanratkaisutaidon arvioinneille, ja toisella virkkeellä rajataan ensimmäistä tutkimusta. PIAAC keskittyy ongelmiin, jotka liittyvät nimenomaan tieto- ja viestintätekniikan käyttöön. Tietokoneet ja tietoverkot sisältävät paljon tietoa, josta on valittava relevantti ja luotettava, ja tietotekniikka mahdollistaa monipuolisen ja joustavan viestinnän. Ongelmanratkaisu tietoteknisessä ympäristössä tapahtuu konkreettisten ja käytännöllisten tehtävien tekemisenä. 
PIAAC:n ensimmäinen ongelmanratkaisututkimus rajataan kolmeen kontekstiin: henkilökohtaiseen, ammatilliseen ja kansalaisena toimimiseen. Vastaaja ei voi rutiininomaisesti toimimalla saada vastausta ongelmaan, vaan hänen on aktiivisesti laadittava ratkaisu omien tavoitteidensa ja suunnitelmiensa avulla. Tätä varten vastaajan on hankittava, tulkittava ja yhdisteltävä tietoa käytössään olevista lähteistä.

Ongelmanratkaisutaidon tehtävien laadintaa jäsennettiin seuraavien piirteiden avulla: kognitiiviset ominaisuudet, teknologiat ja tehtävät. Kognitiivisilla ominaisuuksilla tarkoitetaan tehtävän vaatimaa (1) tavoitteenasettelua ja edistymisen seurantaa, (2) suunnittelua ja oman työn organisointia, (3) tiedon hankkimista ja arviointia, sekä (4) tiedon käyttöä. Teknologiat ovat niitä välineitä ja sovellusohjelmia, joita tarvitaan ongelman ratkaisemisessa. Ensimmäisessä arvioinnissa käytetään vain tietokonetta ja muutamaa sovellusta (internet, taulukkolaskenta ja sähköposti). Tehtäviä arvioitiin kolmen ominaisuuden avulla: tehtävän konteksti (henkilökohtainen, ammatillinen tai kansalaisena toimiminen), tehtävän vaikeus ja ongelmanasettelun selkeys.

\section{TAUSTAKYSELY}

Taustakysely pyrkii kattamaan olennaiset tekijät, jotka teorian tai empiiristen tutkimusten mukaan ovat yhteydessä tutkittavien perustaitojen hallintaan ja kehittymiseen. Kaikkia taustakyselyn kysymyksiä ei kysytä jokaiselta haastateltavalta, vaan tietokone ohjaa annettujen vastausten perusteella haastattelijaa kysymään kultakin vastaajalta oikeat kysymykset.

Taustakyselyllä kerätään mm. seuraavanlaista tietoa (OECD 2011):

Haastateltavan ikä ja sukupuoli, haastateltavan kotitalouteen liittyviä kysymyksiä, kuten lasten lukumäärä ja ikä sekä puolison pääasiallinen toiminta, ja kysymyksiä haastateltavan taustasta, kuten syntymämaa, kielitaito, hänen vanhempiensa syntymämaa ja koulutus.

Koulutus. Tietoja kysytään haastateltavan hankkimasta muodollisesta tutkintoon johtavasta koulutuksesta, mahdollisesta nykyisestä opiskelusta ja muuhun niin työpaikalla kuin sen ulkopuolella järjestettyn koulutukseen osallistumisesta.

Nykyinen työtilanne ja työhistoria sekä nykyinen tai viimeisin työ. Tietoja kysytään haastateltavan ammatista, työtehtävistä, työpaikasta ja työnantajasta, mahdollisuuksista vaikuttaa omaan työhönsä, työssä oppimisesta ja ansioista.

Geneeristen taitojen käyttö työssä. Tämä osa sisältää erilaisiin työssä käytettäviin geneerisiin taitoihin liittyviä kysymyksiä, ja vastauksista johdetaan geneerisiä taitoja (esim. yhteistyö, vuorovaikutus, viestintä, ongelmanratkaisu) kuvaavia indikaattoreita.

Lukutaidon, numerotaidon ja tietoteknisten taitojen käyttö työssä ja työn ulkopuolella. Kysytään, kuinka usein haastateltavan työhön ja arkielämään työn ulkopuolella sisältyy erilaisia lukemista, kirjoittamista, numerotaitoa ja tietoteknisiä taitoja vaativia tilanteita.

Kansainvälisen vertailtavuuden takaamiseksi taustakysely on sama kaikissa maissa. Joiltain osin, esimerkiksi muodollisen koulutuksen osalta, taustakyselyä jouduttiin mukauttamaan kansallista tilannetta vastaavaksi, mutta vertailukelpoisuus säilyttäen.

\section{ARVOKAS KANSAINVÄLINEN TIETOVARANTO}

Kun arviot vastaajien lukutaidosta, numerotaidosta ja ongelmanratkaisutaidosta tietoteknisessä ympäristössä yhdistetään heidän taustatietoihinsa, saadaan laaja ja monipuolinen tutkimusaineisto, josta moni tutkija voi lohkaista oman palasensa ja käyttää sitä tutkimustyössään. Ainutlaatuista on se, että nyt voidaan tutkia suoraan mitattujen taitojen, eikä esi- 
merkiksi vain koulutuksen, yhteyttä suureen taustatekijöiden joukkoon. Nyt saadaan selville, millaisilla väestöryhmillä on puutteita perustaitojen hallinnassa, mitkä tekijät ovat yhteydessä taitojen kehittymiseen ja heikkenemiseen ja mitä seurauksia niin yksilölle kuin yhteiskunnalle on hyvällä ja huonolla perustaitojen hallinnalla (tästä tarkemmin artikkelissa Malin 2010, 52-53).

Tutkimus tuottaa tietoa myös työelämän taidoille asettamista vaatimuksista. Työntekijöiden todellisten taitojen vertaaminen työelämän tarpeisiin mahdollistaa sen arvioimisen, kuinka hyvin työelämän tarpeet ja työntekijöiden osaamispotentiaali vastaavat toisiaan, ja kuinka paljon ilmenee osaamisvajetta ja ylikompetenssia. Tutkimuksen taustakyselystä saadaan runsaasti tietoa työn sisällöstä, sen edellyttämästä koulutustasosta ja työkokemuksen määrästä, työssä oppimisesta ja työjärjestelyistä työpaikoilla sekä näiden yhteyksistä työtyytyväisyyteen ja työuraan eri ammateissa ja aloilla. Lisäksi saadaan laajempaa valaistusta mm. työttömyyden taustatekijöihin ja positiivisten siirtymien edistämiseen työmarkkinoilla. (Weijola 2010.)

Kun työtehtävät, ammatit ja jokapäiväinen elinja toimintaympäristö muuttuvat, tarvitsemme erilaista osaamista kuin aiemmin. PIAAC-tutkimuk- sen tuottama tieto aikuisten nykyisestä osaamisesta ja työvoimahallinnon tieto rekrytointitarpeista voivat olla lähtökohtana uudenlaiselle koulutustarpeiden pohdinnalle ja käytännön toimille. (Lempinen 2010.)

PIAAC-tutkimus tuottaa rikkaan ja monipuolisen kansainvälisen tietovarannon, jota voidaan hyödyntää jatkotutkimuksissa, opinnäytetöissä, kongressiesitelmissä, tieteellisissä artikkeleissa ja eri kohderyhmille suunnatuissa kirjoituksissa ja esitelmissä. Tutkimusaineiston ja tulosten luotettavuus ja kansainvälinen vertailukelpoisuus varmistetaan varsin yksityiskohtaisella kansainvälisellä ohjeistuksella, jota kaikkien osallistujamaiden on noudatettava ja jonka noudattamista myös tarkkaan seurataan.

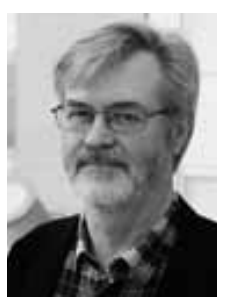

ANTERO MALIN

professori, FT, koulutustutkimuksen kvantitatiivinen metodologia PIAAC-tutkimuksen kansallinen tutkimusjohtaja Koulutuksen tutkimuslaitos, Jyväskylän yliopisto

\section{LÄHTEET}

Carpentieri, JD, Litster, J. \& Frumkin, L (2010). Adult numeracy. A review of research. Research report commissioned by BBC Learning and conducted by NRDC. London: NRDC. http://www.nrdc.org. uk/publications_details.asp?ID=170\#. (Viitattu 16.02.2012.)

De Coulon, A., Meschi, E. \& Vignoles, A. (2008). Parents' basic skills and their children's test scores. Results from the BCS70, 2004 parents and children assessments. London: NRDC. http://www.nrdc. org.uk/publications_details.asp?ID=142\#. (Viitattu 16.02.2012.)

Keeley, B. (2007). Human capital. How what you know shapes your life. OECD 2007.

Levy, F. (2010). How technology changes demands for human skills. OECD Education working paper No. 45.
Lempinen, P. (2010). Tuoko PIAAC aikuisten osaamisen näkyväksi? Teoksessa R. Laukkanen (toim.) PISA, PIAAC, AHELO. Miksi ja miten OECD mittaa osaamista? Opetus- ja kulttuuriministeriön julkaisuja 2010:17, 58-61. http://www.minedu.fi/ OPM/Julkaisut/2010/Miksi_ja_miten_OECD_mittaa_ osaamista.html

Linnakylä, P., Malin, A., Blomqvist, I. \& Sulkunen, S. (2000). Lukutaito työssä ja arjessa. Aikuisten kansainvälinen lukutaitotutkimus Suomessa. Jyväskylän yliopisto. Koulutuksen tutkimuslaitos.

Malin, A. (2010). Kansainvälinen aikuistutkimus PIAAC: Mitä se mittaa? Mitä uutta tietoa se tuo? Teoksessa R. Laukkanen (toim.) PISA, PIAAC, AHELO. Miksi ja miten OECD mittaa osaamista? Opetus- ja kulttuuriministeriön julkaisuja 2010:17, 49-53. 
http://www.minedu.fi/OPM/Julkaisut/2010/Miksi_ja_ miten_OECD_mittaa_osaamista.html

NIACE Committee of Inquiry on Adult Numeracy Learning (2011). Numeracy counts. Final report. http://shop.niace.org.uk/numeracy-counts.html. (Viitattu 16.02.2012.)

OECD (2011). PIAAC conceptual framework of the background questionnaire main survey.

OECD (2012). Literacy, Numeracy and problem solving in technology rich environments: Framework for the OECD survey of adult skills. OECD Publishing. http:// dx.doi.org/10.1787/9789264128859-en

OECD \& Statistics Canada (1995). Literacy, economy and society. Results of the first International Adult Literacy Survey. Pariisi \& Ottawa.

OECD \& Statistics Canada (2000). Literacy in the information age. Final report of the International Adult Literacy Survey. Pariisi \& Ottawa.

OECD, HRDC \& Statistics Canada (1997). Literacy skills for the knowledge society. Further results from the International Adult Literacy Survey. Pariisi \& Ottawa.
Parsons, S. \& Bynner, J. (2005). Does numeracy matter more? London: NRDC. http://www.nrdc.org.uk/ publications_details.asp?ID=16. (Viitattu 16.02.2012.)

Sulkunen, S., Välijärvi, J., Arffman, I., HarjuLuukkainen, H., Kupari, P., Nissinen, K., Puhakka, E., \& Reinikainen, P. (2010). PISA 2009 ensituloksia. 15-vuotiaiden nuorten lukutaito sekä matematiikan ja luonnontieteiden osaaminen. Opetus- ja kulttuuriministeriö \& Koulutuksen tutkimuslaitos, Jyväskylän yliopisto.

Weijola,V. (2010) PIAAC-tutkimukselta odotetaan uusia eväitä koulutus- ja työvoimapolitiikan muotoiluun: Kommentteja työvoimapolitiikan näkökulmasta. Teoksessa R. Laukkanen (toim.) PISA, PIAAC, AHELO. Miksi ja miten OECD mittaa osaamista? Opetus- ja kulttuuriministeriön julkaisuja 2010:17. 54-57. http://www.minedu.fi/OPM/Julkaisut/2010/ Miksi_ja_miten_OECD_mittaa_osaamista.html 